\title{
MINAPOLITAN UNTUK MENDUKUNG KETAHANAN DAN KEAMANAN PANGAN
}

\author{
Bambang Pujiasmanto, Sutopo, Istijabatul Aliyah dan Mulyanto \\ Pusat Penelitian Pedesaaan dan Pengembangan Daerah LPPM UNS \\ Email: bpmanto@yahoo.com
}

\begin{abstract}
The objectives of this research were to: (1) identify the potentials of fish resources in Klaten regency which can be developed as the economic generator of the community; (2) analyze the provision of fish products to support food security and safety for the surroundng region; (3) analyze the process of managing fish to perform food safety and security; 4) analyze the supporting factors of fish resources management in Klaten to develop the community economy; 5) analyze the constraints of managing fish resources in Klaten to develop the community economy; 6) analyze the policy and programs of the local Government of Klaten in developing the potenstials of fish resources; particularly fish cultivation; and (7) formulize an appropriate method to manage fish resources to improve the community economy and support food security and safety. This research applied descriptive approach and was qualitative in nature. Data were collected using several methods including site observation, in-depth interview, focus group discussion, document study, and super impose. Sampling technique used in this research were purposive sampling and snowball. Data were analyzed using (1) Human Resources Analysis (2) Policy Analysis (3) Interactive Analysis. Research results include: (1) method to manage fish resources to improve the community economy and support the food security and safety; 2) recommendation in the form of Memorandum of Understanding (MOU) related to the method to manage fish resources to improve the community economy and support the food security and safety; and 3) handouts concerning method to manage fish resources to improve the community economy and support the food security and safety.
\end{abstract}

Keywords: community economy, fish resources, food sacurity and safety

\section{PENDAHULUAN}

\section{Latar Belakang}

Indonesia memiliki potensi sumber daya alam yang berlimpah untuk dimanfaatkan secara tepat, arif dan berkelanjutan guna meningkatkan kesejahteraan masyarakat. Salah satu potensi sumber daya alam tersebut adalah berbagai jenis sumber daya kelautan dan perikanan. Pemerintah telah berupaya untuk mengembangkan potensi sumber daya kelautan dan perikanan melalui berbagai kebijakan, antara lain dengan Konsepsi Minapolitan salah satunya adalah perikanan. Kebijakan Pemerintah untuk mengembangkan perikanan tersebut tertuang di dalam Peraturan Menteri Kelautan dan Perikanan Republik Indonesia Nomor PER.12/MEN/2010 tentang Minapolitan. Menurut Peraturan Menteri tersebut Minapolitan adalah sebuah konsepsi pembangunan ekonomi kelautan dan perikanan berbasis kawasan berdasarkan prinsip-prinsip terintegrasi, efisiensi, berkualitas dan percepatan. Di dalam pengembangan Minapolitan, Kementerian Kelautan dan
Perikanan RI telah menetapkan kawasankawasan yang potensial dan prospektif yang menjadi Kawasan Minapolitan. Di dalam Peraturan Menteri Kelautan dan Perikanan RI Nomor PER.12/MEN/2010 tentang Minapolitan, disebutkan bahwa yang dimaksud Kawasan Minapolitan adalah suatu bagian wilayah yang mempunyai fungsi utama ekonomi yang terdiri dari sentra produksi, pengolahan, pemasaran komoditas perikanan, pelayanan jasa, dan/atau kegiatan pendukung lainnya. Dengan demikian pada dasarnya Kawasan Minapolitan merupakan kawasan dengan pusat kegiatan utama ekonomi yang memanfaatkan, mengelola dan membudidayakan sumber daya kelautan dan perikanan serta mempunyai keterkaitan fungsional dengan sistem permukimannya yang dikembangkan untuk mendorong pertumbuhan ekonomi lokal dan menumbuhkan daya saing regional.

Di samping menerbitkan Peraturan Menteri, dalam rangka mengembangkan Kawasan Minapolitan pada tahun 2010 Kementerian Kelautan dan Perikanan Republik 
Indonesia juga menerbitkan Keputusan Menteri Kelautan dan Perikanan Republik Indonesia Nomor KEP.32/MEN/2010 tentang Penetapan Kawasan Minapolitan. Di dalam Keputusan Menteri tersebut disebutkan bahwa Kementerian Kelautan dan Perikanan Republik Indonesia telah menetapkan 197 Kawasan Minapolitan di 33 Provinsi di Indonesia dan akan dilaksanakan secara bertahap mulai tahun 2010 sampai dengan tahun 2014. Sampai dengan tahun 2010 baru terealisasi sebanyak 41 Kawasan Minapolitan. Kawasan Minapolitan tersebut tersebar di seluruh wilayah nusantara mengingat Indonesia adalah negara maritim yang mempunyai kekayaan sumber daya wilayah pesisir dan lautan yang sangat besar. Oleh karena itu pengembangan Kawasan Minapolitan menjadi salah satu program unggulan Kementerian Kelautan dan Perikanan. Sampai dengan 14 Mei 2010 pada saat ditetapkannya Keputusan Menteri Kelautan dan Perikanan Republik Indonesia Nomor KEP.32/MEN/2010 tentang Penetapan Kawasan Minapolitan terdapat 197 Kabupaten/Kota yang ditetapkan sebagai daerah pengembangan Kawasan Minapolitan. Di Provinsi Jawa Timur terdapat 10 (sepuluh) Kabupaten dan 1 (satu) Kota yang ditetapkan sebagai Kawasan Minapolitan, dan salah satunya adalah Kabupaten Pacitan (Pencanangan dan Rapat Koordinasi Pelaksanaan Minapolitan di Kabupaten Pacitan : PPP Tamperan, 8 Juni 2010).

Pengembangan Kawasan Minapolitan dalam hal ini difokuskan pada pengembangan sumber daya perikanan diarahkan pada pemberdayaan masyarakat dengan memberikan peran yang optimal kepada masyarakat guna meningkatkan perekonomian dan kesejahteraan mereka. Bahkan pengembangan sumber daya perikanan merupakan salah satu kebijakan strategis untuk menanggulangi kemiskinan guna meningkatkan kesejahteraan rakyat. Namun demikian, meskipun dikembangkan dengan pendekatan kerakyatan atau pendekatan pembangunan berbasis masyarakat, pengembangan sumber daya perikanan harus menjunjung tinggi asas kelestarian fungsi lingkungan kawasan sehingga manfaat pengembangannya dapat dinikmati baik oleh generasi sekarang maupun generasi yang akan datang (anak cucu kita). Dengan demikian asas konservasi demi kelestarian fungsi lingkungan hidup juga harus dipegang erat dan dikelola dengan baik agar lingkungan alam dapat lestari serta mendukung ketahanan dan keamanan pangan.

Ide dasar pengembangan sumber daya perikanan adalah penguatan sinergi antara peningkatan perekonomian masyarakat dan dukungan terhadap ketahanan dan keamanan pangan, serta upaya penemuan metode pengelolaan sumber daya perikanan berikut instrumen-instrumen yang dapat menjamin kelestarian fungsi lingkungan hidup untuk pembangunan wilayah yang berkelanjutan. Pemberdayaan masyarakat melalui pengembangan sumber daya perikanan dapat meliputi pengintegrasian sumber daya terkait seperti sumber daya air, keragaman ikan, hasil pertanian dan sumber daya manusia yang sangat mendukung.

Lebih jauh lagi, mengingat pengembangan sumber daya perikanan ini menggunakan potensi lokal, maka konsep ini sangat mendukung perlindungan dan pengembangan budaya sosial lokal (local social culture) serta perekonomian lokal, termasuk usaha mikro, kecil dan menengah (UMKM). Kabupaten Klaten memiliki potensi yang dapat memenuhi persyaratan sebagaimana disebutkan di atas. Oleh karena itu pengembangan sumber daya perikanan di Kabupaten Klaten sesuai dengan karakteristik potensi sumber daya alam serta sumber daya manusia yang dimiliki.

\section{Tujuan Penelitian}

1. Mengindentifikasi potensi sumber daya perikanan di Kabupaten Klaten yang dapat dikembangkan sebagai pembangkit perekonomian masyarakat.

2. Menganalisis ketersediaan produk ikan untuk mendukung ketahanan dan keamanan pangan bagi wilayah sekitarnya.

3. Menganalisis proses pengelolaan hasil ikan dalam rangka mewujudkan ketahanan dan keamanan pangan.

4. Menganalisis faktor pendukung pengelolaan sumber daya perikanan di Kabupaten Klaten untuk meningkatkan perekonomian masyarakat.

5. Menganalisis faktor penghambat pengelolaan sumber daya perikanan di Kabupaten Klaten untuk meningkatkan perekonomian masyarakat.

6. Mengkaji kebijakan dan program Pemerintah Kabupaten Klaten dalam mengembangkan potensi sumber daya 
perikanan, khususnya potensi perikanan budidaya.

7. Merumuskan metode yang tepat untuk mengelola sumber daya perikanan dalam rangka meningkatkan perekonomian masyarakat dan mendukung ketahanan dan keamanan pangan.

\section{Studi Pustaka}

A. Pengelolaan Sumber Daya Ikan

Sebagai negara kepulauan Indonesia memiliki potensi sumber daya ikan yang sangat besar dan memiliki keanegaraman hayati yang tinggi, di mana perairan Indonesia memiliki $27,2 \%$ dari seluruh spesies flora dan fauna yang terdapat di dunia yang meliputi $12,0 \%$ mammalia, 23,8\% amphibia, 31,8\% reptilia, $44,7 \%$ ikan, 40,0\% molluska, dan 8,6\% rumput laut (Mallawa, 2006).

Pengelolaan sumber daya ikan merupakan suatu aspek yang sangat menonjol di sektor perikanan dan ketidakmampuan pengelolaan sumber daya ikan/sumber daya perikanan dapat berakibat pada menurunnya pendapatan sektor perikanan dari sumber yang ada. Mengingat pengelolaan sumber daya ikan mempunyai cakupan yang luas dan pengalaman kita dalam bidang pengelolaan juga masih terbatas maka diperlukan suatu kesamaan dalam mengartikan kata pengelolaan sumber daya ikan. Kata "pengelolaan" merupakan terjemahan dari kata "management". Dalam ilmu administrasi management memiliki unsur pokok yang terdiri atas POAC, yakni planning, organizing, actuating, dan controlling. Pengelolaan perikanan adalah suatu proses yang terintegrasi, mulai dari pengumpulan informasi, analisis, perencanaan, konsultasi, pengambilan keputusan, alokasi sumber dan implementasinya dalam upaya menjamin kelangsungan produktivitas serta pencapaian tujuan pengelolaan. Dalam pengelolaan sumber daya ikan diperlukan adanya beberapa batasan yang perlu mendapat perhatian, antara lain: (1) besaran daerah pengelolaan, (2) siapa pengelolanya, dan (3) bagaimana cara pengelolaannya (Mallawa, 2006).

Di dalam Undang-Undang Nomor 31

Tahun 2004 Tentang Perikanan disebutkan bahwa pengelolaan perikanan adalah semua upaya termasuk proses yang terintegrasi dalam pengumpulan informasi, analisis, perencanaan, konsultasi, pembuatan keputusan, alokasi sumber daya ikan, dan implementasi serta penegakan hukum dari peraturan perundang-undangan di bidang perikanan yang dilakukan oleh pemerintah atau otoritas lain yang diarahkan untuk mencapai kelangsungan produktivitas sumber daya hayati perariran dan tujuan yang telah disepakati. Adapun tujuan pengelolaan sumber daya ikan adalah sebagai berikut.

(1) Meningkatkan taraf hidup nelayan kecil dan pembudidaya ikan skala kecil;

(2) Meningkatkan penerimaan dan devisa negara;

(3) Mendorong perluasan dan kesempatan kerja;

(4) Meningkatkan ketersediaan dan konsumsi sumber protein ikan;

(5) Mengoptimalkan pengelolaan sumber daya ikan;

(6) Meningkatkan produktivitas, mutu, nilai tambah, dan daya saing;

(7) Meningkatkan ketersediaan bahan baku untuk industri pengolahan ikan;

(8) Mencapai pemanfaatan sumber daya ikan, lahan pembudidayaan ikan, dan lingkungan sumber daya ikan secara optimal; dan

(9) Menjamin kelestarian sumber daya ikan, lahan pembudidaya ikan, dan tata ruang.

Pengelolaan sumber daya ikan berkelanjutan dan berbasis masyarakat adalah pengelolaan yang mengarah kepada bagaimana sumber daya ikan yang ada saat ini mampu memenuhi kebutuhan sekarang dan kebutuhan generasi yang akan datang, di mana aspek keberlanjutan harus meliputi aspek ekologi, sosialekonomi, masyarakat, dan institusi. Pengelolaan sumber daya ikan berkelanjutan menganjurkan untuk memenuhi persyaratan bahwa tingkat pemanfaatan tidak melampaui daya dukung (carrying capacity) lingkungan perairan atau kemampuan pulih sumber daya ikan, sehingga generasi mendatang tetap memiliki aset sumber daya ikan yang sama atau lebih banyak dari yang 
dimiliki oleh generasi saat ini. Bengen dalam Mallawa (2006) menyatakan bahwa suatu pengelolaan dikatakan berkelanjutan apabila kegiatan tersebut dapat mencapai tiga tujuan pembangunan berkelanjutan, yaitu secara ekologi, sosial, dan ekonomi. Berkelanjutan secara ekologi mengandung arti bahwa kegiatan pengelolaan sumber daya ikan dimaksud harus dapat mempertahankan integritas ekosistem, memelihara daya dukung lingkungan, dan konservasi sumber daya ikan, termasuk keanekaragaman hayati sehingga pemanfataan sumber daya ikan dapat berkesinambungan. Keberlanjutan secara sosial mensyaratkan bahwa pengelolaan sumber daya ikan hendaknya dapat menciptakan pemerataan hasil, mobolitas sosial, kohesi sosial, partisipasi masyarakat, pemberdayaan masyarakat, identitas sosial, dan pengembangan kelembagaan. Keberlanjutan secara ekonomi berarti bahwa kegiatan pengelolaan sumber daya ikan harus dapat membuahkan pertumbuhan ekonomi, pemeliharaan kapital, dan penggunaan sumber daya ikan serta investasi secara efisien.

B. Peningkatan Pendapatan Masyarakat melalui Pembangunan Ekonomi Kerakyatan

Pembangunan ekonomi adalah suatu proses kenaikan pendapatan total dan pendapatan perkapita dengan memperhitungkan adanya pertambahan penduduk dan disertai dengan perubahan fundamental dalam struktur ekonomi suatu negara. Pembangunan ekonomi tak dapat lepas dari pertumbuhan ekonomi (economic growth). Menurut Mudrajad dalam bukunya Ekonomi Pembangunan: Teori, Masalah dan Kebijakan (2000) dalam Laporan Pendahuluan Penelitian Pengembangan Kawasan Minapolitan Sebagai Daya Tarik Wisata Dan Pusat Pertumbuhan Ekonomi Daerah Kabupaten Pacitan 2011, yang dimaksud dengan pembangunan ekonomi adalah suatu proses dimana pendapatan perkapita suatu negara selama kurun waktu yang panjang selalu meningkat dengan catatan jumlah penduduk yang hidup di bawah garis kemiskinan absolut tidak meningkat dan distribusi pendapatan tidak semakin timpang. (Mudrajad, 2000:57).
Definisi lain tentang pembangunan ekonomi dikemukakan oleh Arsyad (1999:6) yang mengartikan pembangunan ekonomi sebagai proses yang menyebabkan kenaikan pendapatan riil perkapita penduduk suatu negara dalam jangka panjang disertai oleh perbaikan sistem kelembagaan. Dari definisi di atas, pembangunan ekonomi mengandung beberapa konsep dasar, yaitu:

a. Suatu proses yang berarti perubahan yang terjadi terus menerus;

b. Usaha untuk menaikkan pendapatan perkapita;

c. Kenaikan pendapatan itu harus terus berlangsung dalam jangka panjang;

d. Perbaikan sosial dan budaya sistem kelembagaan. Hal ini dapat ditinjau dari dua aspek, yaitu perbaikan organisasi (institusi) dan perbaikan di bidang regulasi (baik formal maupan informal);

Menurut Suryana dalam bukunya Ekonomi Pembangunan: Problematika dan Pendekatan (2000) Laporan Pendahuluan Penelitian Pengembangan Kawasan Minapolitan Sebagai Daya Tarik Wisata dan Pusat Pertumbuhan Ekonomi Daerah Kabupaten Pacitan 2011, terdapat empat teori atau model pembangunan ekonomi yang bisa diterapkan khususnya dalam pembangunan di Indonesia, yaitu sebagai berikut :

1. Model pembangunan yang berorientasi pertumbuhan. Tujuan pokok strategi ini adalah meningkatkan laju produksi (GDP). Kenaikan GDP (Gross Domestic Product) merupakan faktor utama dan merupakan parameter ekonomi dan sosial yang paling baik untuk tingkat hidup suatu masyarakat;

2. Model pembangunan ekonomi yang berorientasi pada penciptaan lapangan kerja. Sasaran yang dicapai adalah peningkatan dalam kesempatan kerja produktif dan meningkatkan produksi dengan cara redistribusi pendapatan melalui perluasan lapangan kerja untuk mengurangi pengangguran;

3. Model pembangunan yang berorientasi pada penghapusan kemiskinan. Tujuan strategi ini mengurangi kemiskinan, peningkatan kesempatan kerja produktif dan peningkatan GNP 
(Gross National Product) atau peningkatan pendapatan kelompok miskin. Strategi ini dapat dilakukan dengan redistribusi kekayaan harta produktif melalui kebijaksanaan fiskal dan kredit, pemanfaatan fasilitasfasilitas, reorientasi produksi melalui proyek padat karya dan relokasi sumberdaya produktif yang menguntungkan golongan miskin melalui pengalihan investasi dan konsumsi serta penekanan sektor tradisional dan sektor informal di perkotaan;

4. Model pembangunan yang berorientasi pada pemenuhan kebutuhan dasar (The Bassic Necessary Oriented). Antara lain Pertama tercapainya investasi yang tinggi dengan pemanfaatan tehnologi tepat guna dan penggunaan sumber daya alam dalam produksi secara efisien, Kedua adanya perubahan dalam pola redistribusi dengan melakukan mobilitas pengangguan, relokasi pelayanan jasa umum dan land reform, Ketiga perlunya aspek perubahan kelembagaan, yang meliputi partisipasi masyarakat dan dukungan pemerintah.

Secara nyata pembangunan ekonomi mendorong pertumbuhan ekonomi, dan sebaliknya, pertumbuhan ekonomi memperlancar proses pembangunan ekonomi. Yang dimaksud dengan pertumbuhan ekonomi adalah proses kenaikan kapasitas produksi suatu perekonomian yang diwujudkan dalam bentuk kenaikan pendapatan nasional. Suatu negara dikatakan mengalami pertumbuhan ekonomi apabila terjadi peningkatan GNP riil di negara tersebut. Adanya pertumbuhan ekonomi merupakan indikasi keberhasilan pembangunan ekonomi.

Pertumbuhan ekonomi dalam pengertian ekonomi makro adalah penambahan produk domestik bruto (PDB), yang berarti peningkatan pendapatan nasional. Pertumbuhan ekonomi ada dua bentuk: extensively yaitu dengan penggunaan banyak sumberdaya (seperti fisik, manusia atau natural capital) atau intensively yaitu dengan penggunaan sejumlah sumberdaya yang lebih efisien (lebih produktif).
Ketika pertumbuhan ekonomi dicapai dengan menggunakan banyak tenaga kerja, hal tersebut tidak menghasilkan pertumbuhan pendapatan perkapita. Namun ketika pertumbuhan ekonomi dicapai melalui penggunaan sumberdaya yang lebih produktif, termasuk tenaga kerja, hal tersebut menghasilkan pendapatan perkapita yang lebih tinggi dan meningkatkan standar hidup rata-rata masyarakat.

Terdapat beberapa faktor yang mempengaruhi pertumbuhan dan pembangunan ekonomi. Namun pada hakikatnya faktor-faktor tersebut dapat dikelompokkan menjadi dua, yaitu faktor ekonomi dan faktor nonekonomi.

a. Faktor ekonomi yang mempengaruhi pertumbuhan dan pembangunan ekonomi diantaranya adalah sumberdaya alam, sumberdaya manusia, sumberdaya modal, dan keahlian atau kewirausahaan.

1) Sumberdaya alam, yang meliputi tanah dan kekayaan alam seperti kesuburan tanah, keadaan iklim dan cuaca, hasil hutan, tambang dan hasil laut, sangat mempengaruhi pertumbuhan industri suatu negara, terutama dalam hal penyediaan bahan baku produksi;

2) Sumberdaya modal atau investasi dibutuhkan manusia untuk mengolah bahan mentah tersebut. Pembentukan modal dan investasi ditujukan untuk menggali dan mengolah kekayaan. Sumber daya modal berupa barang-barang modal sangat penting bagi perkembangan dan kelancaran pembangunan ekonomi karena barang-barang modal juga dapat meningkatkan produktivitas. Investasi ini bisa dibentuk dari investasi dalam negeri yang diambil dari tabungan masyarakat dan cadangan, serta investasi luar negeri atau asing;

3) Sumberdaya manusia juga menentukan keberhasilan pembangunan nasional melalui jumlah dan kualitas penduduk. Jumlah penduduk yang besar merupakan pasar potensial untuk memasarkan hasil-hasil produksi, sementara kualitas penduduk 
menentukan seberapa besar produktivitas yang ada;

4) Keahlian dan kewirausahaan dibutuhkan untuk mengolah bahan mentah dari alam, menjadi sesuatu yang memiliki nilai lebih tinggi (disebut juga sebagai proses produksi).

b. Faktor non-ekonomi mencakup kondisi sosial kultur yang ada di masyarakat, keadaan politik, dan sistem yang berkembang dan berlaku.

C. Peningkatan Pendapatan Masyarakat melalui Pembangunan Ekonomi Kerakyatan

Ketahanan pangan adalah kondisi terpenuhinya pangan bagi individu dan rumah tangga yang tercermin dari tersedianya pangan yang cukup, baik jumlah maupun mutunya aman merata dan terjangkau, sebagaimana yang diamanatkan dalam UU No.7 Tahun 1996. Ketahanan harus dapat diwujudkan secara mandiri, agar menjadi sumber mata pencaharian dan bahan pangan dapat tersedia secara local (Kantor Ketahanan Pangan Enrekang, 2011).

\section{METODE PENELITIAN}

Lokasi penelitian ini akan dilaksanakan di Kabupaten Klaten dengan pertimbangan potensi dan permasalahan yang ada di Kabupaten Klaten terkait dalam Pengembangan Kawasan Minapolitan (Desa Nila) yang telah ditetapkan oleh Bupati Klaten dengan SK Bupati No. 523.3/124/2009 tanggal 6 Maret 2009 dan di resmikan oleh Bapak Gubernur pada tanggal 10 Maret 2009, disamping itu pula diperkuat dengan adanya keputusan Direktorat Jenderal Perikanan Budidaya Nomor KEP. 70/DJ-PB/2010 tentang Penetapan 24 Lokasi Sentra Produksi Perikanan Budidaya, dan Kabupaten Klaten termasuk dalam kawasan percontohan sentra produksi perikanan budidaya tahun 2011 .

\section{Teknik Pengumpulan Data}

Dalam melakukan penelitian ini akan dipergunakan teknik pengumpulan data melalui observasi, wawancara, dan checklist data pada instansi terkait, serta melakukan pengamatan langsung di lapangan. Sedangkan untuk memperoleh masukan pada saat perumusan masalah, pengenalan tantangan dan peluang, sampai pada penyempurnaan hasil perumusan metode pengelolaan, akan dilakukan melalui metoda Focus Group Discussion (FGD).

Teknik cuplikan yang digunakan dalam penelitian ini adalah purposive sampling dan snowball sampling. Metode purposive sampling dilakukan dengan mengambil sampel berdasarkan alasan bahwa orang-orang kunci yang dipilih dari masyarakat dan aparat pemerintah khususnya pihak yang terlibat dalam Pengembangan Sumber Daya Perikanan di Kabupaten Klaten yang benar-benar mengetahui permasalahan yang terkait dengan penelitian ini. Teknik snowball akan dilakukan untuk menentukan informan dengan menghubungi tokoh kunci pertama dari masyarakat dan aparat pemerintah yang dipilih dan mencari tokoh kunci berikutnya dari informasi tokoh kunci pertama dan seterusnya sampai data yang diperlukan terpenuhi. Dengan teknik ini diharapkan peneliti akan mendapatkan key informants yang memadai.

Diagram 1: Analisis Interaktif.

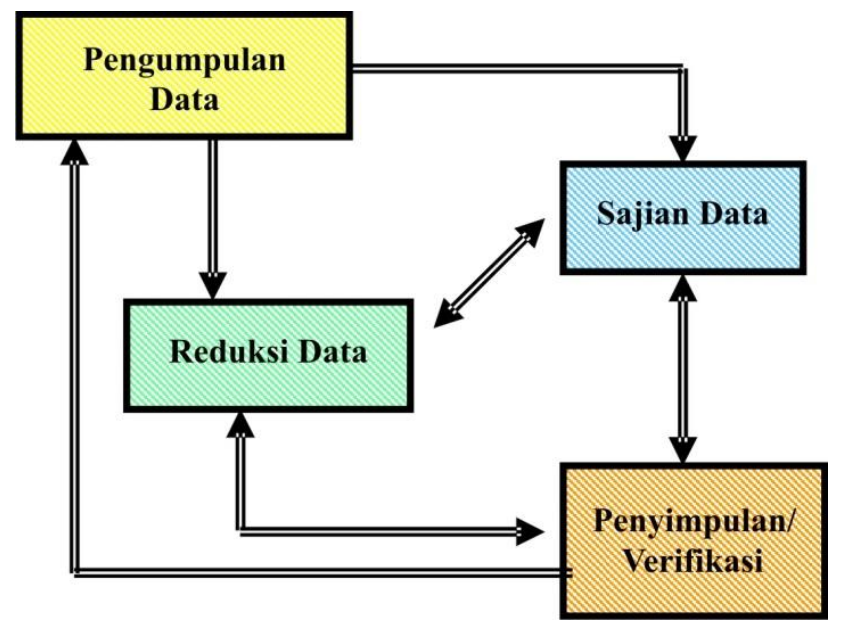


Diagram 2: Analisis Tematik.

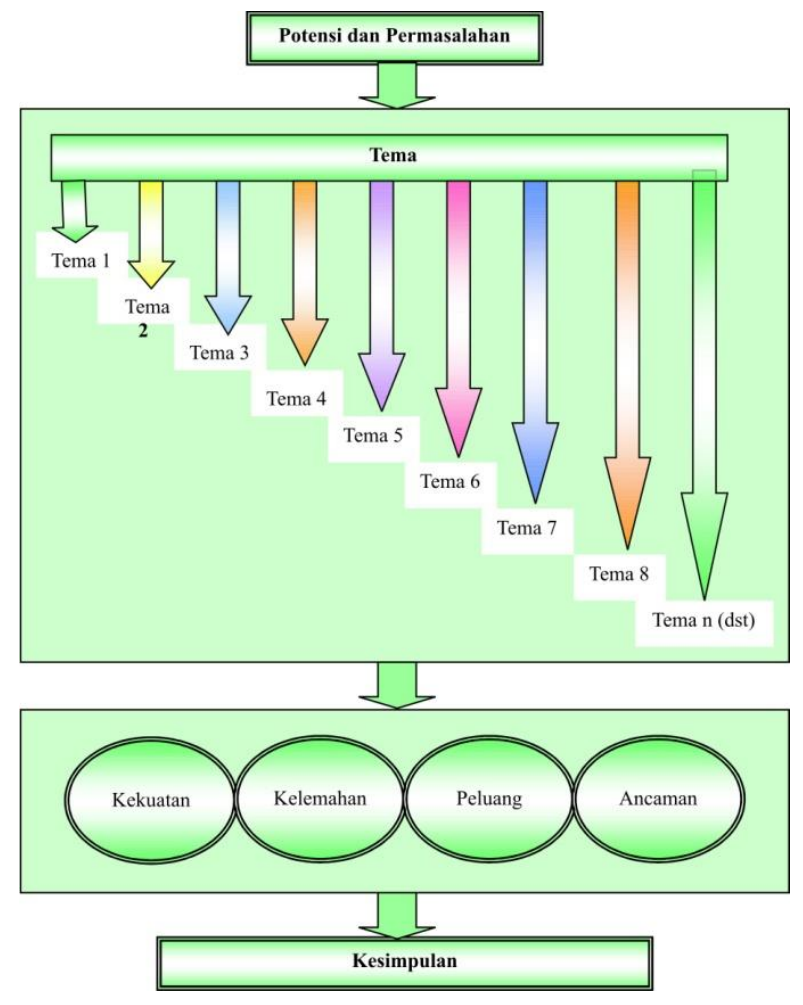

\section{HASIL DAN PEMBAHASAN}

Ketahanan pangan merupakan suatu sistem yang terdiri dari subsistem ketersediaan, distribusi, dan konsumsi. Subsistem ketersediaan pangan berfungsi menjamin pasokan pangan untuk memenuhi kebutuhan seluruh penduduk, baik dari segi kuantitas, kualitas, keragaman dan keamanannya. Subsistem distribusi berfungsi mewujudkan sistem distribusi yang efektif dan efisien untuk menjamin agar seluruh rumah tangga dapat memperoleh pangan dalam jumlah dan kualitas yang cukup sepanjang waktu dengan harga yang terjangkau. Sedangkan subsistem konsumsi berfungsi mengarahkan agar pola pemanfaatan pangan secara nasional memenuhi kaidah mutu, keragaman, kandungan gizi, kemananan dan kehalalannya. Situasi ketahanan pangan di negara kita masih lemah. Hal ini ditunjukkan antara lain oleh: (a) jumlah penduduk rawan pangan (tingkat konsumsi < $90 \%$ dari rekomendasi 2.000 $\mathrm{kkal} / \mathrm{kap} / \mathrm{hari}$ ) dan sangat rawan pangan (tingkat konsumsi $<70 \%$ dari rekomendasi) masih cukup besar, yaitu masing-masing 36,85 juta dan 15,48 juta jiwa untuk tahun 2002; (b) anak-anak balita kurang gizi masih cukup besar, yaitu 5,02 juta dan 5,12 juta jiwa untuk tahun 2002 dan 2003 (Ilham Tawakal, 2010).
Pangan merupakan kebutuhan esensial bagi kelangsungan hidup manusia untuk dapat hidup sehat dan produktif, sehingga pemenuhannya tidak dapat ditunda-tunda. Oleh sebab itu pembangunan pertanian dalam upaya menjaga ketersediaan pangan selalu menjadi prioritas bagi suatu bangsa dan salah satu tujuan pembangunan pertanian adalah menjaga agar ketahanan pangan tetap terkendali. Pangan dalam konteks ini bukan hanya beras, ikan, daging, sayuran dan buahbuahan tetapi termasuk juga pangan olahan dan air. Oleh karena pangan merupakan kebutuhan utama manusia maka pangan harus dikelola, diatur, dan dijaga keberadaannya sehingga ketersediaannya dapat berkesinambungan. Hal ini tersirat dalam Undang-Undang Nomor 7 Tahun 1996 tentang pangan, dimana pangan merupakan kebutuhan dasar manusia yang pemenuhannya menjadi hak asasi setiap rakyat Indonesia dalam mewujudkan sumberdaya manusia yang berkualitas dan produktif.

Disamping pangan sebagai kebutuhan dasar manusia, kebutuhan pangan akan meningkat terus menerus seiring dengan peningkatan jumlah penduduk, sementara disisi lain laju peningkatan produksi pangan berjalan lambat (rendah), dan dalam era globalisasi menyebabkan impor berbagai jenis pangan tidak dapat dihindarkan. Melihat kenyataan ini akan menempatkan Indonesia menjadi suatu negara dengan tingkat ketahanan pangan (food insecurity) yang membahayakan. Disamping itu impor pangan yang tidak terkendali menyebabkan petani tidak bisa memasarkan hasil usahanya sehingga akan kehilangan sumber pendapatannya.

Menurut Bustanul Arifin (dalam Ilham Tawakal, 2010) ketahanan pangan merupakan tantangan yang mendapatkan prioritas untuk mencapai kesejahteraan bangsa pada abad milenium ini. Apabila melihat Penjelasan PP $68 / 2002$ tersebut, upaya mewujudkan ketahanan pangan nasional harus bertumpu pada sumber daya pangan lokal yang mengandung keragaman antar daerah.

Permasalahan yang menghambat dalam mencapai ketahanan pangan dan menjauhkan Indonesia dari keadaan rawan pangan adalah konversi lahan pertanian menjadi daerah industri. Menurut Tambunan (dalam Ilham Tawakal, 2010) dengan semakin sempitnya lahan pertanian ini, maka sulit untuk 
mengharapkan petani kita berproduksi secara optimum. Diperkirakan bahwa konversi lahan pertanian ke nonpertanian di Indonesia akan semakin meningkat dengan rata-rata 30.00050.000 ha per tahun, yang diperkirakan jumlah petani gurem telah mencapai sekitar 12 juta orang.

\section{KESIMPULAN}

Potensi sumber daya perikanan di Kabupaten Klaten sebagai pembangkit perekonomian masyarakat cukup besar. Potensi tersebut berupa ikan nila dan banyak terdapat di Kecamatan Karanganom, Tulung dan Polanharjo. Ketersediaan produk ikan untuk mendukung ketahanan pangan dan keamanan pangan bagi wilayah sekitarnya cukup baik, jumlah produksi tertinggi di Kecamatan Polanharjo. Proses pengelolaan hasil ikan dalam rangka mewujudkan ketahanan dan keamanan pangan utamanya ditentukan oleh ketersediaan air yang sehat sehingga produk ikan aman untuk dikonsumsi.

\section{UCAPAN TERIMAKASIH}

Tim peneliti Pusat Penelitian Pedesaan dan Pembangunan Daerah (PUSLITDESBANGDA) Lembaga Penelitian dan Pengabdian kepada Masyarakat (LPPM) Universitas Sebelas Maret mengucapkan terima kasih yang sebesar-besarnya kepada Direktorat Penelitian dan Pengabdian kepada Masyarakat (DP2M) Direktorat Jenderal Pendidikan Tinggi (DIKTI) Kementerian Pendidikan dan Kebudayaan RI yang telah memberikan kesempatan dan kepercayaan serta memfasilitasi dana penelitian melalui program penelitian Strategi Nasional, sehingga penelitian mengenai "Pengembangan Metode Pengelolaan Sumber Daya Perikanan untuk Meningkatkan Perekonomian Masyarakat dan Mendukung Ketahanan Dan Keamanan Pangan" yang hasilnya telah kami rangkum d alam artikel ilmiah ini, dapat terselenggara dengan baik.

\section{DAFTAR PUSTAKA}

.2010. Minapolitan.

http://lovescokelat.wordpress.com/2010/0 1/06/minapolitan/ Diunduh: 19-4-2011

BAPPEDA. 2009. Review Rencana Pembangunan Jangka Menengah Daerah (RPJMD) Kabupaten Klaten Tahun 20062010. Klaten: BAPPEDA.
Danandjaja, James, 1997. Folklor Indonesia Ilmu gosip, dongeng, dan lain-lain. Jakarta: Grafiti.

Fitrawan Umar. 2011. Minapolitan, Kota Untuk Nelayan. http://fitrawanumar.blogspot.com/2011/0 3/minapolitan-kota-untuknelayan.htmlDiunduh: 19-4-2011.

Hayes, N. 1997. Doing qualitative analysis in psychology. Dalam Rara Sugiarti. (1998). The potential for developing ecologically sustainable rural tourism in Surakarta, Central Java, Indonesia. A master thesis. James Cook University Australia.

Ilham Tawakal, 2010, Menuju Ketahanan Pangan,

http://sosbud.kompasiana.com/2010/01/0 9/tantangan-menuju-ketahanan-pangan/

Kantor Ketahanan Pangan Enrekang, 2011, http://enrekangkkp.wordpress.com/2011/0 6/17/kantor-ketahanan-pangan-enrekang/

Krisnamurthi, Bayu. 2003. "Usaha Mikro, Kecil dan Menengah: Ekonomi Rakyat dengan Cara Berekonomi Mereka Sendiri". Makalah disampaikan pada Kongres XV ISEI (Ikatan Sarjana Ekonomi Indonesia) di Malang Jawa Timur, 13-15 Juli.

Kvale, S. 1996. Interviews: an introduction to qualitative research interviewing. Dalam Rara Sugiarti. (1998). The potential for developing ecologically sustainable rural tourism in Surakarta, Central Java, Indonesia. A master thesis. James Cook University Australia.

Laksono, 2006, Mossaik: Lakon Ujar Wayang Beber. Dalam Luqman Haroni Said, 2008, Seni Pertunjukan Wayang Beber di Desa Gedompol, Kecamatan Donorojo, Kabupaten Pacitan Dalam Telaah Bentuk, Fungsi, dan Makna Program Studi Pendidikan Bahasa dan Sastra Indonesia Jurusan Pendidikan Bahasa dan Seni Fakultas Keguruan dan Ilmu Pendidikan Universitas Muhammadiyah Malang.

Leila Retno Komala, 2003, "Peranan NilaiNilai Tradisional dalam Kehidupan Modern dan Integrasi Bangsa", naskah pidato pembukaan Simposium Nasional'Peranan Nilai-Nilai Tradisional dalam Kehidupan Modern dan Integrasi 
Bangsa', tanggal 13 Januari di Surakarta (Kerjasama Forum Komunikasi dan Informasi Keraton Nusantara dan Bappenas).

Martani Huseini, Sudarsono Hardjosoekarto, Heru Nurasa dan Threesye Mariman. (1993). Pengembangan Usaha Berskala Kecil di Indonesia. Analisis CSIS No.02 Th XXII, Maret-April, hal. 151-176.

Miles, M. B. \& Huberman. A. M. 1984. Qualitative Data Analysis: A Sourcebook of New Methods. London: Sage Publications.

Moleong, Lexy J. 1987. Metode Penelitian Kualitatif. Bandung: CV. Remaja Karya.

Peraturan Daerah Kabupaten Klaten No.7/2009. Rencana Pembangunan Jangka Panjang Daerah Kabupaten Klaten Tahun 2005-2025;

Picard, Michel, 1992. Bali: Pariwisata Budaya dan Budaya Pariwisata. Jakarta: Gramedia.

PPM (Pendidikan dan Pembinaan Manajemen). 1997. Informasi Kredit Usaha Kecil, Seri Menajemen Bank No.5. Jakarta: PT Pustaka Bina-man Pressindo.
PT. Andalan Rereka Consultindo, 2012, Fasilitasi Pengembangan Kawasan Tertinggal Bengkalis, http://www.penataanruang.net/ta/Lapdul0 4/P4/Bengkalis/Bab1.pdf

Pusat Pengkajian Fiskal dan Moneter. 1996. Mencari Bentuk Kemitraan Pemerintah LSM dalam Pengentasan Kemiskinan. Seri Kajian Fiskal dan Moneter No.11. Jakarta: Pertama. Jakarta: CFMS (Center for Fiscal and Monetary Studies).

Rara Sugiarti dkk, 2011, Laporan Pendahuluan Penelitian Pengembangan Kawasan Minapolitan Sebagai Daya Tarik Wisata Dan Pusat Pertumbuhan Ekonomi Daerah Kabupaten Pacitan, Balitbang Kabupaten Pacitan.

Tedi Sutardi. $2007 . \quad$ Dalam http://books.google.co.id/ books?id. diunduh tanggal 17 Maret 2009.

Zakaria Bakrie. 2010. Minapolitan Untuk Pembangunan Sektor Perikanan. http://www.luwutimurkab.go.id/lutim2/in dex.php?option=com_content $\&$ view $=$ arti cle\&id=898: minapolitan-untukpembangunan-sektor-perikanan \&catid $=78$ Diunduh: 19-4-2011. 